\author{
Jean Andrei ${ }^{1}$ \\ Zaharia Marian ${ }^{2}$ \\ Gogonea Rodica Manuela ${ }^{3}$ \\ Petrache Dan Cosmin ${ }^{4}$ \\ Zaharia Radu ${ }^{5}$
}

JEL: E24, C38, 047

DOI:10.5937/industrija44-12677

UDC: 331.109 .214

330.59

Original Scientific Paper

\title{
Sustainable Wages and Need for Convergence in EU-28 Countries
}

\author{
Article history: \\ Received: 11 August 2016 \\ Sent for revision: 2 Seprember 2016 \\ Received in revised form: 1 November 2016 \\ Accepted: 8 November 2016 \\ Available online: 30 December 2016:
}

\begin{abstract}
In context of recent transformation of the EU economic and social model, assuring sustainable wages for workers represents a great challenge. The effects of economic crisis have imposed numerous shifts in productivity frontier and labor productivity. Despite the fact that the wage's level have been improved recently, the need for adjustments is still more actual. The main aim of this paper is to analyze if the wage level is sustainable and it assures a proper living standard in accordance to EU-28 economic and social model. In addition, a model of wages evolution is described.
\end{abstract}

Keywords: annual net earnings, convergence, cluster analysis, wages.

\section{Održivost zarada i potreba za konvergencijom sa zaradama u EU-28 zemljama}

Apstrakt: U kontekstu nedavnih promena u privredi i društvenom razvoju u EU, obezbeđenje održivosti zarada za radnike predstavlja veliki izazov. Pod uticajem ekonomske krize došlo je do pomeranja granice produktivnosti koju radnici trebaju da ostvare. Pored toga što je došlo do usklađivanja nivoa zarada, I dalje se potrebna dalja usklađivanja. Cllj ovog rada je da analizira da li su zarade održive I da li obezbeđuju dovoljan životni standard u skladu sa

\footnotetext{
${ }^{1}$ Petroleum-Gas University of Ploiesti, Romania,

2 Petroleum-Gas University of Ploiesti, Romania

${ }^{3}$ Bucharest University of Economic Studies, Romania

${ }^{4}$ Bucharest University of Economic Studies, Romania

${ }^{5}$ Valahia University of Targoviste, Romania
} 
Andrei J. et al.: Sustainable Wages and Need for Convergence in EU-28 Countries

ekonomskim i društvenim modelom u EU. U radu se takođe opisuje model razvoja zarada.

Ključne reči: Godišnje neto zarade, konvergencija, analiza klastera, zarade.

\section{Introduction}

In contemporary economies labor force represents one of the most determinant resources in achieving economic sustainable development and competitiveness, especially when it comes to transitional economies. The labor force is also an important factor in shaping the economy structure evolution. In EU-28, the labor costs have been dramatically increasing during the years which it has imposed a shift of the economic paradigm. Searching for the cheap and well trained labour force has become a major turning point both for the old EU-28 member states and also for the new European emergent economies. The evolution of the labour force costs has triggered controversial phenomenon as industrial capacity relocation to more labor cost friendly zones in EU-28, productivity frontiers changes and numerous labor force movements and brain drain.

The subject of sustainable wages and need for convergence in EU-28 countries was poorly exploited and analyzed during the years, especially from the Romanian perspective.

Wages represent a quite reliable indicator in approaching the labor force movements and convergence. Analyzing the wages level, in context of the EU-28, the economic changing paradigm may constitute one of the most reliable actions in understanding the evolution of the European labor force market. Numerous studies in the field argue the importance of wage in shaping the economic performance and capital movements.

In this context, (Ciutacu and Chivu, 2007) analyzing the quality of work and work force occupation in Romania describe a very concerning panorama regarding these aspects on inland workforce. They argue that Romanian labor force despite its high qualification, the level of wages; salaries and other workrelated revenues have influence on economic performance and unemployment. In another study, (Chivu et al., 2015) the analysis included the correlations between incomes and working time in improving the quality of work and employment in Romania. On the contrary, (Mocanu and Serban, 2015) explore the quality of Romanian employment and wages form the territorial level.

Achieving a high level of labor force employed in the economy is fundamental in designing a high competitivity economy. Despite the fact the labor force market is deeply segmented both at the MS state level and EU-28 level, the 
need is recognized to achieve competitivity imposed shift of paradigm where the laborer should be identified itself with the company. The wage level is a factor that could accelerate the process together with investments as: lacovoiu and Panait, (2014), Mieila, (2012) and Mieila, (2016) argue.

Great literature exists on the subject of wage imbalances in the European labour market, such as: Wagner, (2015); Van Gyes and Schulten, (2015); Collignon, (2016); Kretsos and Livanos, (2016); Doran and Fingleton, (2016) on employment resilience and many other studies.

In this context, the main aim of this study was to analyze the existence and sustainable wages' level in EU-28 and if there is need for convergence in EU28 countries. The study started form the assumption that wages are one of the most important indicators in shaping the evolution of the economy in context of economic paradigm changes. Also, in the paper we have tried to develop a model of wages evolution at the Eu-28 level.

\section{Research methodology}

In this study, we have referred to the previous works on the cluster analysis as done by: Gelder, (2014); Zaharia and Gogonea, (2016); Jugănaru and Jugănaru, (2011). For carrying out the research objectives, we used the cluster analysis in order to define possible similarities and dissimilarities among the wages in EU-28. For this reason, we have included not only the EU-28 MS but also 32 countries. To analyze how 32 states included in the analysis were structured in terms of annual net income in 2007, the prior year financial crisis and 2014 respectively, four indicators were included: [SPNC]

1. Single person without children, $100 \%$ of average worker (AW) --

2. One-earner married couple, at $100 \%$ of AW, with two children -[M1E2C],

3. Two-earner married couple, one at $100 \%$, the other at $100 \%$ of AW, with two children -- [M2E2C]

4. Two-earner married couple, one at $100 \%$, the other at $100 \%$ of $\mathrm{AW}$, with no children -- [M2ENC].

The indicators data were collected form Eurostat database (EUROSTAT, 2016, and 2016a)

Following the standard research methodology in using clusters as in (Gelder, (2014); Zaharia and Gogonea, (2016); Jugănaru and Jugănaru, (2011), the 
first step was to design and generate the series of clusters by forming the initial data corresponding to the $m=4$ indicators for each of the $n=36$ states.

The data collected were contained in order to generate the matrix $Y$, as (1):

$$
\text { matrix } Y=\left\|y_{i j}\right\|_{i=\overline{1, n, j}, \overline{1, m}} .
$$

Also, z score was computed using (2):

$$
z_{i j}=\frac{y_{i j}-\bar{y}_{j}}{\sigma_{j}}, \quad \text { where } \bar{y}_{j}=\frac{\sum_{i=1}^{n} y_{i j}}{n}, \quad \sigma_{j}=\sqrt{\frac{\sum_{i=1}^{n}\left(y_{i j}-\bar{y}_{j}\right)^{2}}{n-1}}
$$

For generating Proximity Matrix $\left(W=\left\|w_{i j}\right\|_{i=\overline{1, n, j}=\overline{1, n}}\right.$ ) the Euclidian distance was employed as in (Rotaru, 2006):

$$
W=\left\|w_{i j}\right\|_{i=1, \bar{n}, j=1, n}, \quad w_{i j}=\sqrt{\sum_{i=1}^{n}\left(z_{i k}-z_{i j}\right)^{2}}, j=\overline{1, m}, k=\overline{1, m} j \neq i, k \neq i, w_{i,}(3=0
$$

Also the Ward's method was employed in order to generate and determine the distance between clusters as in (Marinoiu, 2016):

$$
\Delta(A, B)=\sum_{i \in A \cup B}\left\|x_{i}-m_{A \cup B}\right\|^{2}-\sum_{i \in A}\left\|x_{i}-m_{A}\right\|^{2}-\sum_{i \in B}\left\|x_{i}-m_{\mathbf{B}}\right\|^{2}-\frac{n_{A \cap B}}{n_{A \cup B}}\left\|m_{A}-m_{B}\right\|^{2}(4
$$

In (4), A and B are two clusters, $m_{i}$ is the centroid, $n_{i}$ is the number of elements from cluster $i$. and $x_{i}$ an item.

Also as in previous research, (Zaharia and Gogonea, 2016), it was required to test the significance of belonging to clusters of four variables for which reason was employed NOVA methodology. This methodology could be only applied if the data series between dispersions have no significant differences. For this reason, Levene's test was also used whose null hypothesis is:

$$
H_{0 \_1}: \sigma_{1}^{2}=\sigma_{2}^{2}=\sigma_{3}^{2}=\ldots=\sigma_{r}^{2}
$$

The condition of acceptance of the null hypothesis $\mathrm{H}_{0_{-}}$is: 
Sig.F $>\alpha$ equivalent to $F_{\text {stat }}<F_{\alpha, r-1, n-r}$

When using ANOVA methodology, H0_2 null hypothesis is: between the environments of analyzed variables there is a significant difference (belonging to clusters of variables analysis is not statistically significant). The condition of accepting the null hypothesis is $\mathrm{H} 0 \_2$ :

$F_{\text {stat }}=\frac{\sum_{i=1}^{r}\left(\bar{y}_{i}-\bar{y}_{0}\right)^{2} n_{i} / d f_{1}}{\sum_{i=1}^{r} \sum_{j=1}^{n i}\left(y_{i j}-\bar{y}_{i}\right)^{2} / d f_{2}}<F_{\alpha, r-1, n-r} \quad$ equivalent to $\quad$ Sig. $F>\alpha$

For carrying out the study and processing the data, we have used SPSS as in previous studies: Zaharia and Gogonea, (2016) (Popa, 2008) and Excel as (Oprea and Zacharia, 2011).

\section{Results and discussion}

To highlight the characteristics and development trends of the period, the net annual income of families used cluster analysis and time series analysis over the period 2001-2015.

\subsection{Clusters structure in 2007}

Taking into account the data series available (earn_nt_net, 2016), as well as different calculations (earn_net_esms, 2016), to highlight the group states based on the annual net income of 28 states currently in the EU, the analysis included only 26 states, as for two EU28 states (Cyprus and Croatia) data were unavailable for the years when the analysis was performed (2007 and 2014). Also, for comparability purposes, the analysis included six states which are not EU members: Iceland, Switzeland, Turkey, United States and Japan.

Cluster analysis has focused on four indicators: Single person Without children, $100 \%$ of average worker (SPNC) One-earner married couple, at $100 \%$ of average worker (AW) with two children (M1E2C) Two-earner married couple, one at $100 \%$, the other at $100 \%$ of AW, with two children (M2E2C) and Two-earner married couple, one at $100 \%$, the other at $100 \%$ of AW, with no children (M2ENC). The first year for which the cluster analysis was performed using the Euclidean distance obtained dendrogram 2007 respectively Ward's method is illustrated in Figure 1. 
Figure 1. Dendrogram using Ward Linkage for the year 2007
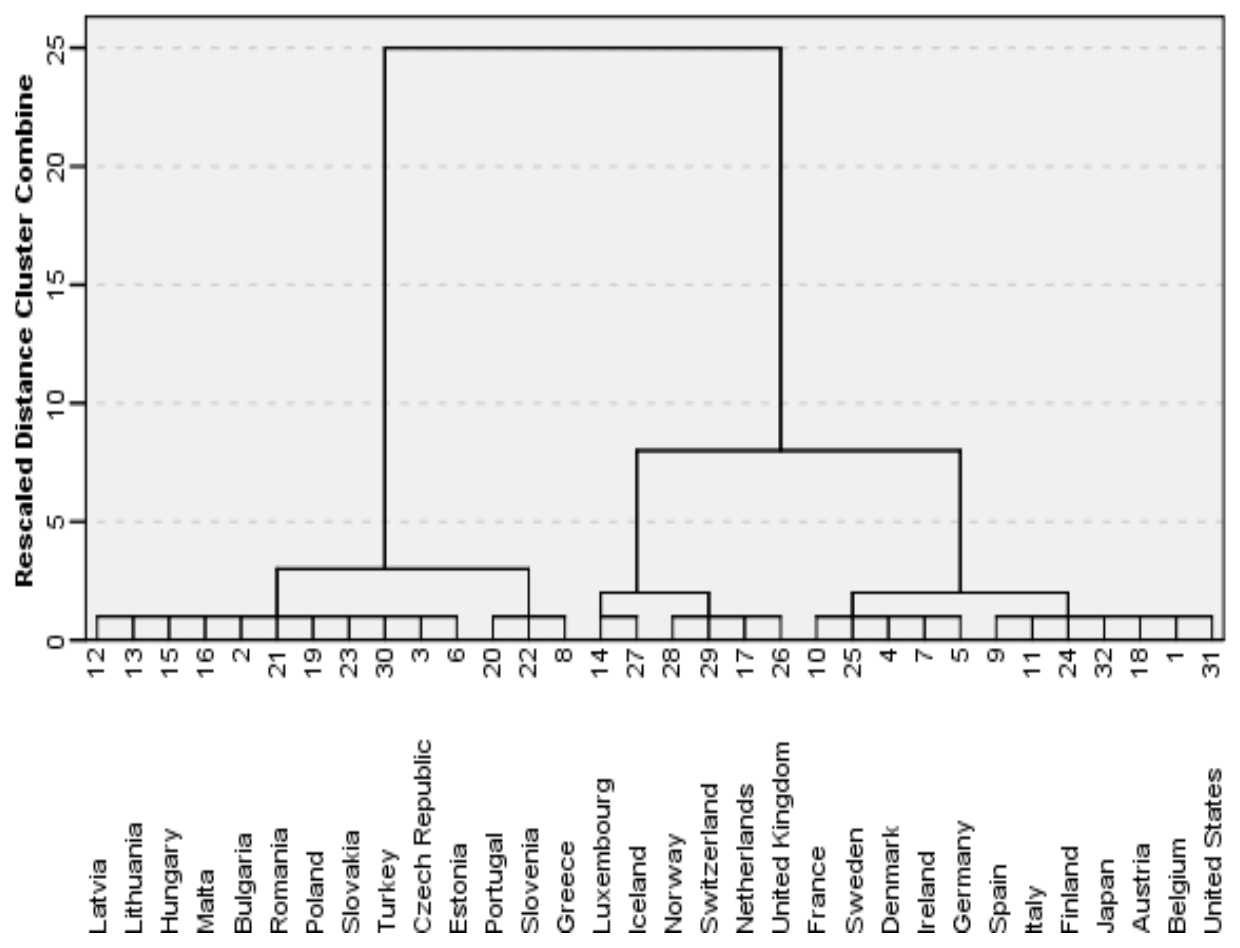

Source: own construction using SPSS

Looking at figure 1, 32 states can be grouped into two to six clusters. To better highlight the grouping according to four indicators, we chose the group in six clusters. Six clusters (Table 1) include, besides four EU states, non EU countries. Thus, the cluster $\mathrm{C} 1$ contains, in addition to $10 \mathrm{EU}$ countries, a non EU country (Turkey), the cluster C3 contains one EU country (Luxembourg) and one non EU country (Iceland), cluster C4 contains two EU Member States (Netherlands and United Kingdom) and two non-EU countries (Norway, Switzerland), and cluster 6 contains, besides four EU states, two non EU countries (United states, Japan). 
Andrei J. et al.: Sustainable Wages and Need for Convergence in EU-28 Countries

Table 1 Structure of clusters determinants by SPNS, M1E2C, M2E2C and M2ENC in the year 2007

\begin{tabular}{|c|l|l|}
\hline \multirow{2}{*}{ Cluster } & \multicolumn{2}{|c|}{ Countries included in clusters } \\
\cline { 2 - 3 } C1 & $\begin{array}{l}|c| \\
\text { Bulgaria, Czech Republic, Estonia, Latvia, } \\
\text { Lithuania, Hungary, Malta, Poland, Romania, } \\
\text { Slovakia }\end{array}$ & Turkey \\
\hline C2 & Greece, Portugal, Slovenia & \\
\hline C3 & Luxembourg & Iceland \\
\hline C4 & Netherlands, United Kingdom & Norway, Switzerland \\
\hline C5 & Denmark, Germany, Ireland, France, Sweden, & \\
\hline C6 & Belgium, Spain, Italy, Austria, Finland, & United States, Japan \\
\hline
\end{tabular}

Source: authors 'own construction using SPSS

H0_1 hypothesis testing of no significant differences between the values of the data series dispersions obtained by grouping of six clusters used Levene's Test. The results obtained are shown in Table 2.

Table 2. Test of Homogeneity of Variances

\begin{tabular}{|c|c|c|c|c|}
\hline & $\begin{array}{c}\text { Levene } \\
\text { Statistic }\end{array}$ & df1 & df2 & Sig.F \\
\hline SPNC & 2.024 & 5 & 26 & 0.108 \\
\hline M1E2C & 0.784 & 5 & 26 & 0.571 \\
\hline M2E2C & 1.969 & 5 & 26 & 0.117 \\
\hline M2ENC & 1.801 & 5 & 26 & 0.148 \\
\hline
\end{tabular}

Source: own construction using SPSS

After testing the condition (5) all Sig.F values $>0.05$ that the null hypothesis HO_1 is accepted and therefore appropriate variables analyzed for significance testing can use ANOVA methodology.

The results obtained from ANOVA are presented in Table 3. Given that for any of the variables not the condition (6) that the null hypothesis $\mathrm{H}_{0} 2$ for all four variables and therefore variables SPNs, M1E2C, M2E2C and M2ENC are significant in terms of belonging to clusters.

Given that the conditions of statistical significance are met for all six clusters corresponding mean values of the variables analyzed clusters (cluster centers) and their characteristics are shown in Table 4. 
Andrei J. et al.: Sustainable Wages and Need for Convergence in EU-28 Countries

Table 3. Results of testing the hypothesis $\mathrm{H}_{0 \_}$regarding the appurtenance of variables

SPNS, M1E2C, M2E2C and M2ENC to clusters

\begin{tabular}{|c|c|c|c|c|c|}
\hline & df1 & df2 & Fstat & $F_{0.05 ; 5 ; 26}$ & Sig.F \\
\hline SPNC & 5 & 26 & 296.555 & 2.59 & 0.000 \\
\hline M1E2C & 5 & 26 & 223.908 & 2.59 & 0.000 \\
\hline M2E2C & 5 & 26 & 304.089 & 2.59 & 0.000 \\
\hline M2ENC & 5 & 26 & 299.039 & 2.59 & 0.000 \\
\hline
\end{tabular}

Source: authors 'own ccomputations using SPSS

Table 4 The values of clusters center (Means) for the SPNS, M1E2C, M2E2C and M2ENC în the year 2007, and their 95\% Confidence Interval for Mean

\begin{tabular}{|c|r|r|r|r|r|r|r|r|r|r|r|r|}
\hline \multirow{2}{*}{$\begin{array}{c}\text { Clus } \\
\text { ter }\end{array}$} & \multicolumn{3}{|c|}{ SPNC } & \multicolumn{4}{c|}{ M1E2C } & \multicolumn{3}{c|}{ M2E2C } & \multicolumn{3}{c|}{ M2ENC } \\
\cline { 2 - 13 } & $\begin{array}{r}\text { Mea } \\
\mathrm{n}\end{array}$ & LB & UB & $\begin{array}{c}\text { Mea } \\
\mathrm{n}\end{array}$ & LB & UB & $\begin{array}{c}\text { Mea } \\
\mathrm{n}\end{array}$ & LB & UB & Mean & LB & UB \\
\hline \multirow{2}{*}{ C1 } & 534 & 431 & 637 & 622 & 489 & 754 & 112 & 912 & 134 & 1069 & 863 & 1275 \\
& 6 & 5 & 7 & 2 & 5 & 9 & 96 & 7 & 65 & 3 & 1 & 5 \\
\hline \multirow{2}{*}{ C2 } & 131 & 846 & 179 & 158 & 119 & 197 & 288 & 155 & 420 & 2718 & 142 & 4010 \\
& 83 & 5 & 02 & 47 & 11 & 83 & 09 & 32 & 85 & 3 & 66 & 0 \\
\hline \multirow{2}{*}{ C3 } & 399 & 840 & 714 & 501 & 403 & 599 & 841 & 827 & 855 & 8073 & 295 & 1319 \\
& 05 & 6 & 03 & 37 & 40 & 33 & 21 & 23 & 18 & 8 & 44 & 31 \\
\hline \multirow{2}{*}{$\mathrm{C} 4$} & 359 & 324 & 393 & 399 & 348 & 450 & 749 & 683 & 815 & 7148 & 652 & 7769 \\
& 20 & 55 & 84 & 46 & 30 & 62 & 89 & 84 & 93 & 3 & 72 & 4 \\
\hline \multirow{2}{*}{$\mathrm{C} 5$} & 267 & 261 & 274 & 322 & 290 & 354 & 569 & 547 & 591 & 5353 & 522 & 5483 \\
& 67 & 17 & 17 & 81 & 78 & 83 & 54 & 62 & 45 & 4 & 34 & 4. \\
\hline \multirow{2}{*}{ C6 } & 227 & 209 & 244 & 265 & 240 & 291 & 480 & 439 & 521 & 4545 & 419 & 4897 \\
& 27 & 67 & 88 & 74. & 28 & 20 & 88 & 80 & 96 & 0.1 & 28 & 2 \\
\hline
\end{tabular}

Source: authors' own computations using SPSS

Results from Table 4 allow highlighting an overall view of the level of development of the variables (SPNs, M1E2C, M2E2C and M2ENC) in 2007, the countries of cluster components. Thus, in relation to the average values of the variables SPNs, M1E2C, M2E2C and M2ENC, a plot was carried out (Figure 2) to highlight them more clearly on clusters.

By studying and comparing the levels of development of four variables clusters, it may indicate that, in 2007, Cluster $1\left(\mathrm{C1}_{2007}\right)$ included most countries (11 countries) compared to the other five clusters. These countries are: Bulgaria, Czech Republic, Estonia, Latvia, Lithuania, Hungary, Malta, Poland, Romania, Slovakia and Turkey. C12007 is characteristic oscillation of annual net earnings of the other nine countries between the minimum level 
established in Bulgaria and the maximum recorded in the Czech Republic, for all four variables analyzed. However, one can still see feature: compared to the other $\left(\mathrm{C}_{2007}, \mathrm{C}_{2007}, \mathrm{C4}_{2007}, \mathrm{C}_{2007}, \mathrm{C6}_{2007}\right)$, this cluster assigned the lowest values of average earnings annual wage net for each variable included in the analysis (5346 euro / worker the country SPNs, 6222 euro / worker the country M1E2C, 11296 euro / worker the country to M2E2C and 10693 euro / worker the country M2ENC).

Figure 2. Evolution of the variables SPNS, M1E2C, M2E2C and M2ENC by clusters in 2007

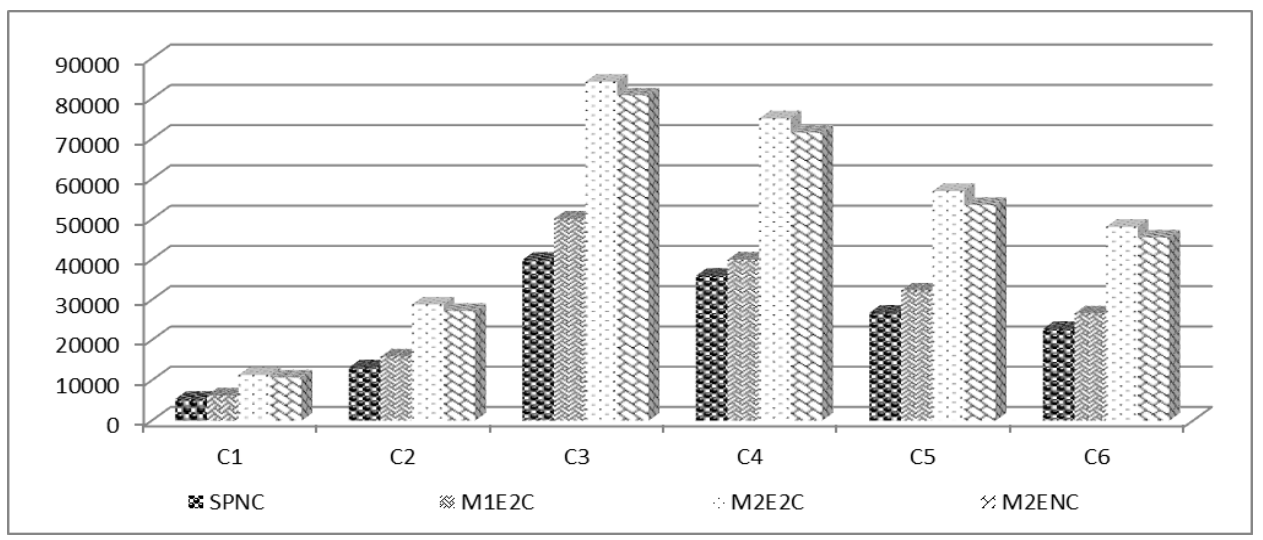

Source: authors 'own computation

The average annual salary net gain of about 2.6 times higher than that of the first cluster, regardless of the variable analyzed, is scheduled for the following cluster $\left(\mathrm{C2}_{2007}\right)$ which has three components countries: Greece, Portugal and Slovenia.

The hierarchical order of increasing average values of earning net annual considering each variable analyzed, with a mean difference of approximately 10 thousand euro / worker country, shows Belgium, Spain, Italy, Austria, Finland, namely the United States and Japan cluster 6 ( $\left.6_{2007}\right)$.

At small difference of averages $\mathrm{C6}_{2007}$ and $\mathrm{C}_{2007}$ almost double the presents cluster $5\left(\mathrm{C}_{2007} 7\right)$ countries: Denmark, Germany, Ireland, France and Sweden.

The first two places are occupied by cluster $3-\mathrm{C}_{2007}$ (Luxembourg and Iceland) and cluster 4- $\mathrm{C}_{2007}$ (Netherlands, United Kingdom or Norway, Switzerland). Average annual net earning for first place are 39905 euro / worker the country SPNs, 50137 Euro / worker the country M1E2C, 84121 Euro / worker the country to M2E2C and 80738 euro / worker the country to 
M2ENC. These are findings about 8 times bigger comparative with those of the cluster $\mathrm{C1}_{2007}$. Regarding average annual wage gain net $\mathrm{C}_{2007}$ (second place), shown in Table 4 that this matter variable is about 7 times higher than the cluster $\mathrm{C1}_{2007}$.

They are presented in Table 4 the values of the environments (Lower and Upper-UB-LB) for the 95\% confidence lever.

Considering that all limit values are the same sign (in this analysis are positive) that each average annual wage Net gain on cluster and variable statistically significant. This highlights openness to providing sustainable wages.

\subsection{Clusters structure in 2014}

The second year for analysis was 2014. They were originally included in the analysis all 32 countries (26 EU member states and non EU states 6). Due to large differences between the annual average income levels in Luxembourg, Norway and Switzerland to other countries included in the analysis at the level of 2014 data series dispersions values of the clusters have made the condition (5) can no longer be met.

Figure 3. Dendrogram using Ward Linkage for the year 2014
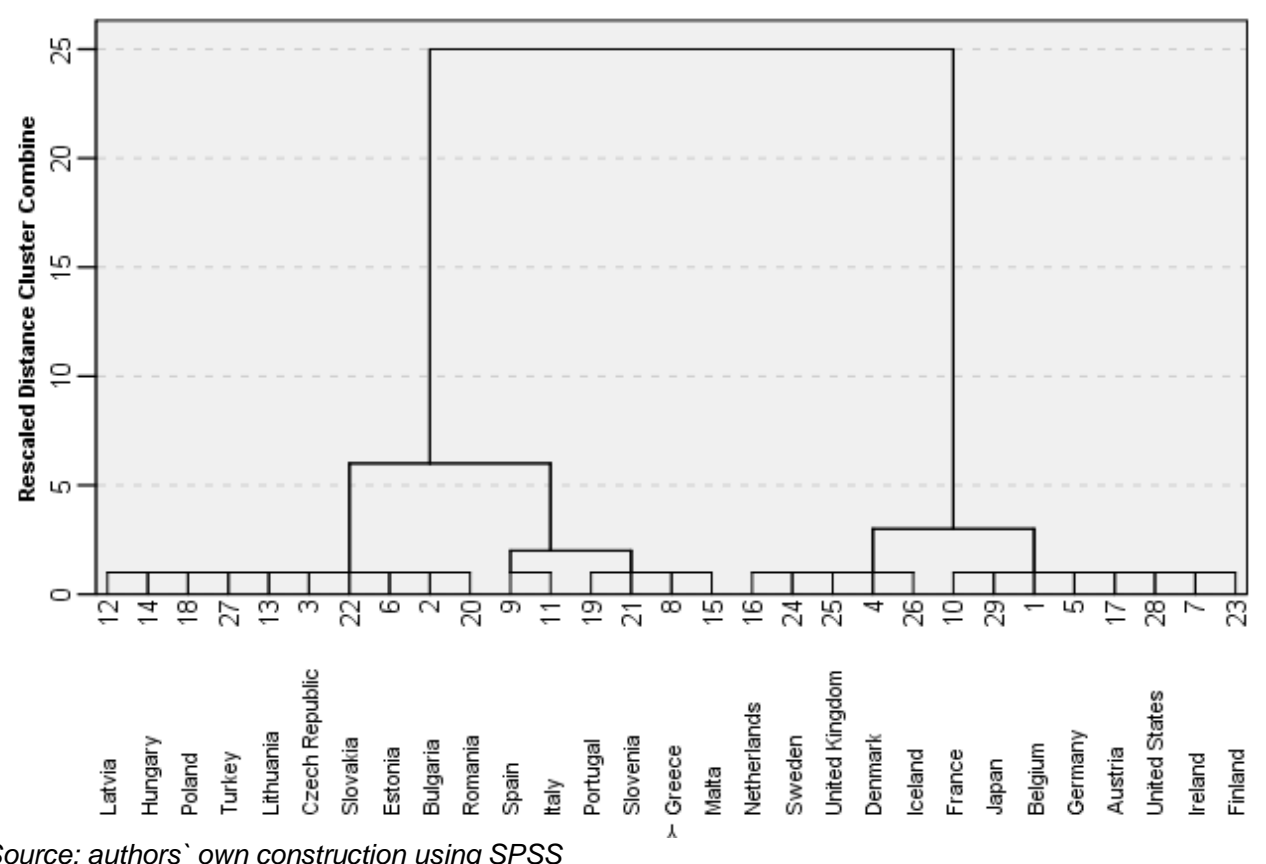

Source: authors 'own construction using SPSS 
However, taking into account that these countries exempted annual net revenue, and since its exclusion from the analysis has significant influence on research findings, they were removed, and the analysus is performed for 29 states, including 25 EU countries and four non EU members (Iceland, Turkey, United States and Japan) that were included in 2007. For comparison, generating clusters was performed using the Euclidean distance and Ward's method respectively. Dendrogram obtained is illustrated in Figure 3.

In Figure 3 two solutions were tested: 4 and 5 of those clusters. For both tested solutions, H0_1 hypothesis of no significant difference between the values of the data series dispersions obtained by the group, the best results were obtained for the solution by 5 clusters (Table 5).

Table 5. Test of Homogeneity of Variances

\begin{tabular}{|c|c|c|c|c|}
\hline & $\begin{array}{c}\text { Levene } \\
\text { Statistic }\end{array}$ & df1 & df2 & Sig.F \\
\hline SPNC & 1.932 & 4 & 24 & 0.138 \\
\hline M1E2C & 0.867 & 4 & 24 & 0.498 \\
\hline M2E2C & 1.180 & 4 & 24 & 0.345 \\
\hline M2ENC & 2.957 & 4 & 24 & 0.041 \\
\hline
\end{tabular}

Source: authors 'own computations using SPSS

After testing the condition (5) variables SPNs, M1E2C and M2E2C Sig.F values $>0.05$, it is found that, for them, the null hypothesis is accepted H0_1 and consequently to test the statistical significance of these variables belonging to clusters, ANOVA methodology can be used. These results are presented in Table 6.

Table 6. Results for testing the hypothesis $\mathrm{H}_{0 \_2}$ regarding variables SPNS, M1E2C and M2E2C appurtenance to clusters using ANOVA

\begin{tabular}{|c|c|c|c|c|c|}
\hline & df1 & df2 & Fstat & $F_{0.05 ; 4 ; 24}$ & Sig.F \\
\hline SPNC & 4 & 24 & 349.324 & 2.78 & 0.000 \\
\hline M1E2C & 4 & 24 & 258.791 & 2.78 & 0.000 \\
\hline M2E2C & 4 & 24 & 295.459 & 2.78 & 0.000 \\
\hline
\end{tabular}

Source: authors ' own computations using SPSS

Given that for any of the three variables, the condition (6) is not met, results that the null hypothesis HO_2 is rejected, therefore SPNs variables values, $\mathrm{M} 1 \mathrm{E} 2 \mathrm{C}$ and M2E2C are statistically significant from the aspect of belonging to clusters.

If the variable M2ENC after using Levene's Test resulted Sig.F $=0.041<0.05$, led to the rejection of the null hypothesis H0_1, and therefore ANOVA can not be applied and Welch's Test was used. 
Andrei J. et al.: Sustainable Wages and Need for Convergence in EU-28 Countries

In this case the test statistic was $F=319.69>F_{0.05,4,7.78}$, respectively $p$ p_value $=0.000<\alpha=0.05$. In these circumstances the null hypothesis is rejected, while the alternative hypothesis is accepted: the average values of variable M2ENC differ significantly in five clusters (cluster membership variable is statistically significant M2ENC).

Five clusters (Table 7) include three EU states and non EU countries. Thus, the cluster $\mathrm{C} 1$ contains, besides 9 EU countries, one non EU country (Turkey), the cluster C4 contains four EU states and one non EU country (Iceland) and cluster C5 contains six EU states and two non EU countries (United States , Japan).

Table 7 Structure of the determined clusters by SPNS, M1E2C, M2E2C and M2ENC in year 2014

\begin{tabular}{|c|l|l|}
\hline \multirow{2}{*}{ Cluster } & \multicolumn{1}{|c|}{ Countries included in clusters } \\
\cline { 2 - 3 } C1 & $\begin{array}{l}|c| \\
\text { Bulgaria, Czech Republic, Estonia, Latvia, Lithuania, Hungary, } \\
\text { Poland, Romania, Slovakia }\end{array}$ & Turkey EU Countries \\
\hline C2 & Spain, Italy, & \\
\hline C3 & Greece, Malta, Portugal, Slovenia & \\
\hline C4 & Denmark, Netherlands, Sweden, United Kingdom & Iceland \\
\hline C5 & Belgium, Germany, Ireland, France, Austria, Finland, & $\begin{array}{l}\text { United States, } \\
\text { Japan }\end{array}$ \\
\hline
\end{tabular}

Source: authors 'own construction using SPSS

The average values of the variables of the analyzed relevant clusters and their characteristics, in 2014, are presented in Table 8.

Table 8 The values of clusters center (means) for the SPNS, M1E2C, M2E2C and M2ENC in 2014, and their 95\% Confidence Interval for Mean

\begin{tabular}{|c|r|r|r|r|r|r|r|r|r|r|r|r|}
\hline \multirow{2}{*}{$\begin{array}{c}\text { Clust } \\
\text { er }\end{array}$} & \multicolumn{4}{|c|}{ SPNC } & \multicolumn{3}{|c|}{ M1E2C } & \multicolumn{3}{c|}{ M2E2C } & \multicolumn{3}{|c|}{ M2ENC } \\
\cline { 2 - 13 } & $\begin{array}{c}\text { Mea } \\
\text { n }\end{array}$ & LB & UB & $\begin{array}{c}\text { Mea } \\
\mathrm{n}\end{array}$ & LB & UB & $\begin{array}{c}\text { Mea } \\
\mathrm{n}\end{array}$ & LB & UB & $\begin{array}{r}\text { Mea } \\
\mathrm{n}\end{array}$ & LB & UB \\
\hline \multirow{2}{*}{ C1 } & 695 & 567 & 822 & 808 & 646 & 969 & 146 & 118 & 174 & 139 & 113 & 164 \\
& 2 & 8 & 7 & 0 & 6 & 5 & 59 & 68 & 50 & 05 & 56 & 53 \\
\hline \multirow{2}{*}{$\mathrm{C} 2$} & 204 & 164 & 244 & 233 & 828 & 383 & 424 & 276 & 572 & 409 & 329 & 489 \\
& 83 & 96 & 71 & 33 & 8 & 77 & 63 & 68 & 57 & 67 & 92 & 42 \\
\hline \multirow{2}{*}{$\mathrm{C} 3$} & 141 & 106 & 176 & 167 & 142 & 191 & 300 & 227 & 372 & 288 & 210 & 367 \\
& 40 & 77 & 03 & 23 & 86 & 60 & 48 & 97 & 99 & 92 & 46 & 37 \\
\hline \multirow{2}{*}{$\mathrm{C} 4$} & 332 & 320 & 345 & 373 & 360 & 386 & 690 & 647 & 733 & 665 & 640 & 691 \\
& 87 & 14 & 59 & 53 & 15 & 91 & 92 & 88 & 95 & 74 & 29 & 19 \\
\hline \multirow{2}{*}{ C5 } & 277 & 268 & 285 & 331 & 312 & 351 & 590 & 572 & 609 & 554 & 538 & 571 \\
& 10 & 50 & 70 & 68 & 28 & 07 & 84 & 50 & 18 & 74 & 07 & 40 \\
\hline
\end{tabular}

Source: own computations using SPSS

Analysis of the results of Table 8 , for the year of 2014, targeting countries components of clusters that can lead to a comparison of the levels of 
development of the four variables: SPNs, M1E2C, M2E2C and M2ENC. Comparing the average values of net annual earnings led to a hierarchy of clusters and a graphical representation (Figure 4) as follows:

$>\quad$ in the top of the hierarchy is the cluster $4\left(C_{2014}\right)$. Average earning annual net is established in relation to average earnings annual wage net of Bulgaria, Czech Republic, Estonia, Latvia, Lithuania, Hungary, Poland, Romania, Slovakia and Turkey to 33287 euro / worker country - SPNs to 37 353 EUR / worker country - M1E2C to 69092 euro / worker country - M2E2C and the 66574 euro / worker country - M2ENC.

$>$ second place is occupied by cluster $5\left(\mathrm{C}_{2014}\right)$. Belgium, Germany, Ireland, France, Austria, Finland, namely the United States and Japan contribute to establishing an average annual net wage for the four variables on average by about 8000 euro / worker country less than in C42014;

Spain and Italy formed cluster $2\left(\mathrm{C}_{2014}\right)$; Annual net earnings are significant for two countries, the average cluster justifying third place;

fourth cluster returns $3\left(\mathrm{C}_{2014}\right)$ countries: Greece, Malta, Portugal and Slovenia. Average annual net earning is about 2.3 times smaller than the cluster C42014 for all variables included in the analysis;

lowest values of average earnings annual wage net (6952 euro / worker the country SPNs, 8080 euro / worker the country M1E2C, 14659 Euro / worker the country to M2E2C and 13905 euro / worker the country M2ENC) correspond to all the first cluster $\left(\mathrm{C1}_{2014}\right)$, as in 2007.

Figure 4. Evolution of the variables SPNS, M1E2C, M2E2C and M2ENC by clusters in 2014

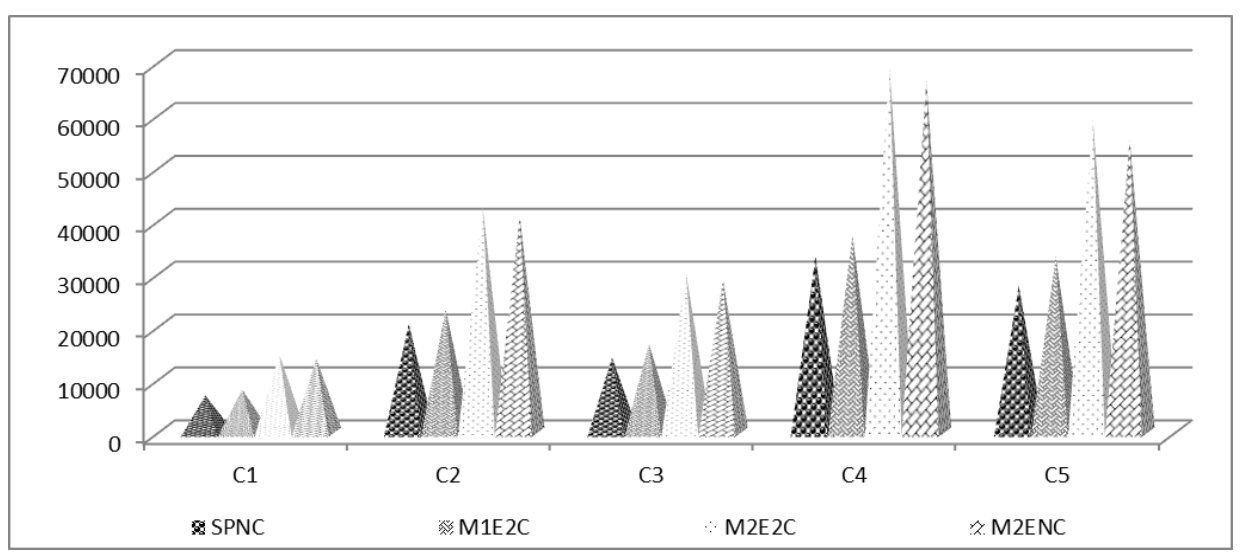

Source: authors' own computation 
Under a probability of $95 \%$ the results from Table 8 show that confidence intervals limit values have the same sign (in this analysis they are positive). Therefore, each average net annual salary and variable cluster is statistically significant in 2014. The results show that the global economic and financial crisis is the result of political strategies applied by countries towards ensuring sustainable wages.

\section{Conclusions}

Evolution trend of the four variables (Single person Without children, $100 \%$ of average worker (AW) [SPNC] One-earner married couple, at $100 \%$ of AW, with two children [M1E2C] Two-earner married couple, one at $100 \%$, the other at $100 \%$ of AW, with two children [M2E2C] Two-earner married couple, one at $100 \%$, the other at $100 \%$ of AW, with no children - [M2ENC]) established and image analysis framework of the annual net earnings, mainly to EU countries.

Comparing 2014 to 2007, significant changes were established in annual net earnings expressed by four variables. Context has revealed significant changes in the countries belonging to clusters. Mutations countries between clusters in 2014 compared to 2007 are reported in relation to the average values of the variables.

During 2007-2014, Malta was facing significant change in annual net earnings as a result of policies and strategies. The result is implemented by changing the cluster of $\mathrm{C} 12007$ in $\mathrm{C} 32014$, which corresponds to annual averages of net earnings, four variables, higher in 2014 compared to 2007. The cluster C1 components remain with all other countries in 2014 and 2007.

Cluster 2 completely changes its composition in 2014 compared to 2007. Thus, Spain and Italy climbed cluster C62007 (which ranks 4 in 2007) and cluster components are C22014 (3rd in 2014). However, the average annual net salary fell in 2014 compared to 2007 for all four variables.

Change in the same direction is found in Greece, Portugal and Slovenia, the cluster C22007. These countries will get from cluster C2 (5th in 2007) in cluster C3 (4th in 2014). The situation is slightly different to the previous one in the sense that, for all four variables will register average annual wage increases in net earnings in 2014 compared to 2007.

The Netherlands and United Kingdom are two EU countries which by policy adopted in 2014 fail to be included in the same cluster C4 as in 2007. This is evidenced by the mean annual net earnings very high both in 2007 and in 2014. In 2014, the composition of the cluster 4 is completed by two countries (Denmark and Sweden). In 2007, these two countries were in C5 and the average annual net salary was lower than the current cluster C42014. 
Iceland, non EU country, in C32007 (1st in 2007) reached C42014 in the cluster occupying first place but all in 2014. Even though the cluster and place it occupied during the analysis does not change this for country, however, one small change is signalled. This change occurs regarding the average annual net salary and it was reduced slightly in 2014 compared to 2007 .

Germany, Ireland and France are the countries in C5 2007 cluster that will be included in the cluster with the same number in 2014. The composition of C52014 cluster will include, along with the three mentioned and EU countries: Belgium, Austria and Finland, namely the United States and Japan, non EU Countries, from C62007. Although in 2014 compared to 2007, the number was changed so hierarchical cluster and place (4th in 2007, 2 in 2014), however, mean annual net earnings are pretty close. This can highlight the efforts of the countries included in the analysis towards ensuring sustainable wages. Socio-economic implications of annual net earnings determined a direct and indirect impact on sustainable economic development in EU countries. The impact causes the growth processes signalled strongly in the context of sustainability event of financial resources, both at the EU level and globally.

\section{References}

Chivu, L., Ciutacu, C., \& Hurley, J. (2007). Incomes and Working Time-Support for Quality of Work and Employment in Romania. Romanian Journal of Economics, 2(34), 47-59. 25.

Ciutacu, C., \& Chivu, L. (2007). Calitatea muncii şi a ocupării forţei de muncă în România. National Institute of Economic Research.European surveys on working conditions.European Foundation for the Improvement of Living and Working Conditions. Retrieved from http://www.eurofound.europa.eu/sites/default/files/ef_files/pubdocs/2007/37/ro/1/ ef0737ro.pdf 2016 May 12.

Collignon, S. (2016). Wage Imbalances in the European Labour Market. Europe in Crisis: A Structural Analysis. Palgrave Macmillan.

Doran, J., \& Fingleton, B. (2016). Employment resilience in Europe and the 2008 economic crisis: Insights from micro-level data. Regional Studies, 50(4), 644656.

-EUROSTAT. (2016). Annual net earnings. earn_nt_net. Retrieved from http://ec.europa.eu/eurostat/data/database $2016 \mathrm{Jul} 25$.

-EUROSTAT. (2016). . earn_net_esms. Retrieved from http://ec.europa.eu/eurostat/cache/metadata/en/earn_net_esms.htm 2016 Jul 25.

Gelder, A. (2014). From Custer to Thermopylae: Last stand behavior in multi-stage contests. Games and Economic Behavior, 87(100), 442-466. 
Andrei J. et al.: Sustainable Wages and Need for Convergence in EU-28 Countries

lacovoiu, V. B., \& Panait, M. (2014). „The Limitation of Investment Development Path Theory. European Union Case". Economic Insights-Trends and Challenges, 3, 33-40.

Jugănaru, I.D., \& Jugănaru, M. (2011). Clusters in Romanian Tourism. Ovidius University Annals, Economic Sciences Series, 11(1), 1107-1111.

Kretsos, L., \& Livanos, I. (2016). The extent and determinants of precarious employment in Europe. International Journal of Manpower, 37(1), 25-43.

Marinoiu, C. (2016). Bootstrap Stability Evaluation and Validation of Clusters Based on Agricultural Indicators of EU Countries. Economic Insights - Trends and Challenges, 5(1), 65-72. LXVIII.

Mieila, M. (2012). Selection of Investment Projects in Situations of Discordance between Criteria of Efficiency Assessment. Valahian Journal of Economic Studies, 3(4), 57-64.

Mieila, M. (2016). Investiţii directe. Eficienţă, finanţare, fezabilitate. Bucharest: Pro Universitaria. in Romanian.

Mocanu, I., \& Serban, P.R. (2015). Exploring the quality of employment in Romania at different territorial levels. Journal of Urban and Regional Analysis, 7(2), 177.

Oprea, C., \& Zaharia, M. (2011). Elemente de analiza datelor și modelare utilizând Excel. București: Ed. Universitară.

Popa, M. (2008). Statistică pentru psihologie. Teorie și aplicații SPSS. Iași: Polirom.

Rotaru, T., Badescu, G., Culic, I., Mezei, E., Mureșan, C., \& ed., (2006). Metode statistice aplicate în științele sociale. (pp. 272-303). lași: Polirom.

van Gyes, G., Schulten, T., \& Eds., (2015). Wage bargaining under the new European Economic Governance: Alternative strategies for inclusive growth. ETUI.

Wagner, I. (2015). Rule Enactment in a Pan-European Labour Market: Transnational Posted Work in the German Construction Sector. British Journal of Industrial Relations, 53(4), 692-710.

Zaharia, M., \& Gogonea, R.M. (2016). A Cluster Analysis of Industrial Production Indices in Some European Countries and Turkey. Economic Insights-Trends \& Challenges, 68(2), 